\title{
Изучение генофонда картофеля в условиях Крайнего Севера
}

\author{
А.Н. Тихановский \\ Всероссийский научно-исследовательский институт ветеринарной энтомологии и арахнологии \\ Тюменского НЦ РАН, Салехард, Россия \\ e-mail:cehanovski@yandex.ru
}

Выращивание картофеля в условиях лесотундровой зоны Обского Севера осложнено наличием ряда негативных природных факторов: поздние весенние и ранние осенние заморозки, а поэтому короткий вегетационный период; в июнеиюле осадков выпадает крайне мало; резкие перепады температуры воздуха ото дня к ночи; мерзлотные почвы с низким содержанием азота; широкое распространение некоторых болезней, особенно ризоктониоза, макроспориоза, парши обыкновенной, мокрой и сухой гнили. Особенно опасные болезни и вредители в районах Севера отсутствуют, но исключение составляют вирусные болезни, которые наносят картофелеводству достаточно сильный урон.

Короткий вегетационный период, дефицит влаги в значительной степени замедлили прохождение всех фенофаз у растений (21-33-38-49 дней) по сравнению со стандартным сортом Хибинский ранний (19-30-33-42 дня). Наряду с этим отмечено повышенное содержание крахмала и сухого вещества в клубнях картофеля: из 94 сортов в коллекции в двух сортах - очень высокое (30,3 \%), в 22 - высокое (16-27\%), в 14 - среднее (14-15,4\%), в стандарте Хибинский ранний $-13,6 \%$.

По комплексу биохимических признаков при выращивании картофеля в условиях Крайнего Севера по урожайности (т/га) и крахмалистости (\%) выделилось 11 сортов: Бежицкий $(17,9-12,9)$, Jbis $(14,9-12,9)$, с-ц 1992 (11,8-16,4), МутагенАгрия (11,1-21,7), Дориза (10,6-129), Quarta $(10,2-15,4)$,Фаленский $(9,71-14,4)$, с-ц К-43 Лайма $(9,70-15,4)$, Северянин $(9,6-15,9)$, Хибинский ранний $(9,1-13,6)$, Famosa $(9,0-15,4)$.

При учете урожая выделилось 6 сортов с повышенным содержанием крахмала и сухого вещества в клубнях (\%): Большевик $(30,8-36,5)$, Наяда $(26-31,8)$, Bekas (25.2-30.9), Елизавета (18-23.7), К-24049 (15,4-21,2), Повировец $(22,7-28,5)$.

Из 94 сортообразцов свободными от всех болезней оказались $87 \%$ (82 сорта). По степени вредоносности (от меньшей к большей) вирусные и грибные болезни расположились в следующем порядке: макроспориоз (Famosa) - скручивание (Juliver) - морщинистая мозаика (Пушкинец, Спиридон) - закручивание (Anosta, Jsola, Laura, Дориза, Ильинский, Северянин, с-ц К-43 Лайма, с-ц К-91). 